Federal Reserve Bank of Minneapolis

Research Department Working Paper

A SUGGESTION FOR OVERSIMPLIFYING

THE THEORY OE MONEY

Neil Wallace*

Working Paper 347

June 1987

NOT FOR DISTRIBUTION

WITHOUT AUTHOR'S APPROVAL

*Federal Reserve Bank of Minneapolis and University of Minnesota.

The views expressed herein are those of the author and not necessarily those of the Federal Reserve Bank of Minneapolis or the Federal Reserve System. The material contained is of a preliminary nature, is circulated to stimulate discussion, and is not to be quoted without permission of the author. 
In his well known paper "A Suggestion for Simplifying the Theory of Money," Hicks [1935] said that the main challenge facing monetary theory is to face up to the frictions that lead people to hold low-yielding monetary-like assets. Today I want to discuss ways of meeting a slightly revised version of that challenge: How do we go about building models which have equilibria in which some assets end up having a relatively low return?

One response is to say that it is easy to meet Hicks' challenge. For example, a model in which the real value of outside money is an argument of individuals' utility functions or one in which holdings of outside money are required to meet a Clower or cash-in-advance constraint will meet the challenge if the stock of outside money is somehow limited. However, such ways of meeting Hicks' challenge seem unconvincing.

Consider the money-in-the-utility-function model. Suppose someone could issue liabilities backed by holdings of interest-bearing securities that would compete with outside money in yielding utility. Such liabilities could be sold at a price that implies a yield lower than the market rate of interest on securities and so earn a profit for the issuer. The same possibility arises in the cash-in-advance model. As usually exposited (Helpman [1981] and Lucas [1982]), in those models individuals face a sequence of two constraints at each date. First, outside money and securities are traded. Then, outside money and goods are traded. But, again, if securities bear interest and if someone in the first market, the money-securities market, could issue liabilities that would trade for goods in the second market, then 
there are potential profits to be earned by doing that. So we are left in these models with the question: What thwarts these profit opportunities?

A boorish response to these concerns consists of simply repeating the assumptions: Outside money is an argument of utility functions not an aggregate of outside and inside money; outside money is needed in the goods market, not either outside or inside money. This is a boorish response, because it stops conversation and leaves us at an impasse. A more forthcoming response would display a willingness to discuss the properties of outside money that allow it to yield utility or to be used for goods purchases and that prevent inside money from playing those roles. Perhaps it is because outside money is trusted and inside money would not be. Or, perhaps such substitution of inside for outside money is limited because the inside money issuers would want to hold reserves in the form of outside money.

While more forthcoming, these responses are not satisfactory. As usually exposited, both money-in-the-utility function and cash-in-advance models have perfect securities markets in which individuals can borrow and lend. If trust is not a problem in those markets, why is it a problem for securities that are going to be exchanged for goods? Nor does there seem to be a need for inside money issuers to hold reserves in such models. In them, all the inside money issues would come due at the same time and could be paid from the proceeds of the assets held as backing. Thus, on the face of it, there is nothing in those models to explain imperfect substitution between outside and inside money. 
The same difficulties arise in the context of models with transactions costs imposed on various market trades. Hicks seemed to advocate such an approach and indeed spelled out the main ingredients of inventory models of money demand. But in such models also, questions about possible substitution of inside for outside money are left unanswered.

It seems, therefore, that we should either abandon the imperfect substitution of inside for outside money or that we should somehow be explicit about the barriers to such substitution and in so doing abandon the perfect securities market assumption of those models. Either has important implications. The first turns those models into ones that do not meet the Hicksian challenge. The second gets us into a very different class of models in which, among other things, propositions like Ricardian equivalence fail because the perfect credit market has been abandoned. Today, I want to pursue the first route. My suggestion--which in the title is referred to as an oversimplifying suggestion--is that there are no natural barriers that limit substitution between privately issued inside money, on the one hand, and outside or government issued money, on the other hand. To explain it, I want to begin by describing in some detail the kind of private intermediation envisaged by this suggestion.

\section{The Oversimplification}

The kind of rate-of-return discrepancies that concern us are those between money-like assets and default-free securities. To begin, it is helpful to be specific and talk about currency, on the one hand, and certain kinds of government debt, on the other 
hand, debt which I will treat as being nominally default free-that is, as being sure titles to currency in the future. First, I want to identify features of such debt that would seem to make it a perfect substitute for currency. Then, given that actual debt does not satisfy those features, I want to consider whether private intermediation could produce those features.

Consider, then, government debt which is pure discount debt, which is payable-to-the-bearer, and whose face values match those of medium-size denomination currency. Let us also make this debt portable so that although distinguishable from currency, say, by its color, it is of similar size and has similar wear and tear properties. As described, this debt differs from currency in only one objective respect; it consists of promises to currency at or after some specified future date, for example, a year from issue date. The question before us is as follows: Conditional on such debt and noninterest bearing currency coexisting, what would be the discount on the debt?

The answer I favor is that such debt, if it coexisted with currency, would sell at face value, at no discount, and be used interchangably with currency. A loose argument for this answer goes like this. Consider first what happens at maturity. At maturity this debt is a demand claim on currency and, so, at that time becomes equivalent to currency. Given what I assumed about its physical characteristics, it should function as currency from then on. Consider next, what happens at a time very close to the maturity date, so close that few if any transactions occur between then and the maturity date. If the debt was going at a 
discount then, almost everyone would prefer it to acquiring actual currency at that time, because the debt will appreciate and the currency will not. Therefore, in order for such debt and currency to coexist at that time, the debt must be accepted at no discount. In other words, it takes on its currency-like character at some time prior to maturity. But if so, then we can repeat the argument and, working backwards, conclude that the debt takes on its currency-like character when it is issued.

In the United States, which is the only country I know a little about, the government does not issue the kind of debt I just described. (Of course, if I am right in what I just asserted, that is not at all surprising. Why go to so much trouble to issue what turns out to be another form of currency?) Until a few years ago, the United States issued Treasury bills which were like the debt described above except that they were issued in very large denominations, no smaller than $\$ 10,000$. Now Treasury bills are all book entry. The United States also issues some smalldenomination Savings bonds, but these are explicitly nonnegotiable and, so, are certainly not payable-to-the-bearer.

Features like nonpayability-to-the-bearer and largedenomination are enough to explain why an individual does not regard such securities as close substitutes for the small amounts of currency that individuals typically hold. But stopping there and saying that that explains why the debt can bear substantial interest would be like saying that a very large per-pound discount on salt purchased in hundred pound sacks is explained by the fact that most people can't lift a hundred pounds. An adequate expla- 
nation should take into account that the best way to break hundred pound sacks into reasonably sized packages does not involve each individual doing it at home in his or her kitchen. Analogously, the best way for substitution between government interest bearing debt and government currency to occur may not be by having individuals do it directly, but, instead, through the activities of financial intermediaries.

Suppose, then, that government debt is like U.S. Treasury bills--large-denomination, pure-discount debt--and consider a financial intermediary that operates as follows. It is like a money-market mutual fund in that it holds only Treasury bills as assets. Its liabilities, however, are designed to compete with government currency--they are small denomination, payable to the bearer, discount securities issued in maturities that match those of the Treasury bills held. Such an intermediary is perfectly hedged so that fraud aside and even without reserves, its notes are as safe as the securities it holds as backing for them. Therefore, if we continue to abstract from fraud, such an activity gives rise to the same situation as prevails if the government itself issues small-denomination, bearer securities. If we suppose that, as part of its business, this intermediary takes actions that prevent fraud, then I conclude, exactly as I did for small-denomination, bearer securities issued by the government, that the bearer notes issued by such intermediaries would sell at par and be used interchangably with currency, if the two were to coexist. 
Since the revenue for this intermediation business comes from buying default-free securities at a discount and issuing bearer notes at par, in an equilibrium with free entry the discount on default-free securities like Treasury bills must be small enough so that it is not profitable to expand this activity. That is the case when the discount is just sufficient to cover the costs of engaging in the business. In other words, in the presence of such intermediation, if currency and government debt of the Treasury bill kind are to coexist, then the yield or nominal rate of return on the latter is bounded above by the least costly way of operating such a financial intermediation business.

Rough estimates of the magnitude of this cost can be inferred from two sources: the cost of operating financial intermediaries in existing intermediary activities and the cost of maintaining currency. Many financial intermediaries--common stock and money market mutual funds--operate at spreads of one percent or less. As for the cost of maintaining currency, in the United States, for all but the smallest denominations the cost is less than one percent of the outstanding stock. These observations suggest that the upper bound on nominal interest rates implied by our hypothetical intermediation is quite low, on the order of one or two percent per year.

We generally do not observe nominal interest rates satisfying such a bound. Nor do we generally observe the kind of intermediation I just described. An obvious explanation of the latter is that it is explicitly prohibited in most countries and has been at most times. I suspect that most countries have laws 
or regulations that in intent and effect are similar to those of the following Canadian statute:

Every bank or other person who issues or reissues, makes, draws or endorses any bill, bond, note, check or other instrument, intended to circulate as money, or to be used as a substitute for money, is guilty of an offense against this act. (Banks and banking law revision act, 1980, 29, Eliz.2, C.40, S 311.1.)

The oversimplifying suggestion ascribes to such restrictions the fact that nominal interest rates do not always satisfy some low upper bound.

\section{Some Positive Implications of the Suggestion}

Now I want to describe some of the positive implications of this suggestion. The sharp implications are those that are implied under laissez-faire in intermediation. They follow from noting that with nominal interest rates bounded above by some rather low constant, real returns on all assets, including those on objects we choose to call monies, must move together. Another way to put this is that under laissez-faire, an attempt to explain the values of all assets by store-of-value considerations should work well.

In some regards, a world with real returns on all assets forced into approximate equality seems bizarre. It is either a world in which currency as we know it--noninterest bearing currency--continues to be valued and all real returns are driven down to approximately that on such currency, or it is a world in which currency as we know it disappears and the currency we use is 
different stuff, perhaps claims denominated in terms of some commodity like ounces of gold, and paying interest, perhaps by selling at a discount and appreciating as a maturity date is approached. Such extreme possibilities were described by Samuelson who, however, was not thinking of approximate rate-ofreturn equality being produced simply by laissez-faire in intermediation:

It is true that in a world involving no transaction friction and no uncertainty, there would be no reason for a spread between the yield on any two assets, and hence there would be no difference in the yield on money and on securities. Hicks concludes, therefore, that securities will not bear interest but will accommodate themselves to the yield on money. It is equally possible and more illuminating to suppose that under these conditions money adjusts itself to the yield of securities. In fact, in such a world securities themselves would circulate as money and be acceptable in transactions; demand bank deposits would bear interest, just as they often did in this country in the period of the twenties. And if money could not make the adjustment, as in the case of metal counters which Aristotle tells us are barren, it would pass out of use, wither away and die, become a free good. [1947, p. 123.]

Each possibility may well seem strange. The view Samuelson favored seems strange because we may have difficulty conceiving of what is, in effect, a cashless society with all transactions being accomplished by the use of interest-bearing instruments. While we can easily conceive of the widespread use 
of debit cards with debits and credits made against interestbearing accounts, we may wonder about their use in all transactions. Wouldn't there remain a demand for currency-like objects, at least for small transactions? And for small transactions, wouldn't it be costly and bothersome to have these objects be interest-bearing? If we answer affirmatively, then we ought to entertain the Hicksian view that all yields fall to the yield on currency--net, however, of the costs of producing and maintaining the currency. In this regard, it should be noted that small denomination currency is somewhat costly to produce and maintain. In the U.S., for example, the cost of maintaining the stock of one dollar bills--which remains in the form of paper despite attempts to introduce a one dollar coin--is approximately three percent of the stock per year. Thus, if currency consists entirely of quite small denomination objects, nominal interest rates higher than the 1 percent or 2 percent mentioned above are consistent with laissez-faire in intermediation. There are, moreover, other grounds for not dismissing too quickly the Hicksian view that, absent frictions, real returns would fall to the yield on currency. Although most economists tend to think in terms of intertemporal models--specifications of preferences and/or technologies--consistent with the Samuelson view, the evidence is far from clear-cut.

In the United States, there have been long periods of very low nominal interest rates. One such period was 1865 to 1913. During this period, National Banks could issue notes provided they held as backing certain eligible government bonds. 
Since these notes circulated as noninterest bearing currency, it is to be expected that the yield on the eligible bonds would have been driven down to a level consistent with zero profits on additional note issue. Yields on eligible bonds were quite low throughout the period. Moreover, throughout the period, some of the bonds eligible to be used as backing were held by the nonbank public, implying that market interest rates in general were tied to the yields on those eligible bonds. It is also to be noted that the period included both deflation and inflation--deflation from about 1873 to 1896 , inflation at about two percent per year form 1896 to 1913. This suggests that real returns were adjusting to the real return on currency. Another period of very low nominal interest rates in the United States began in the 1930's and ended in the early 1950s.

Another kind of evidence that bears on whether preferences and technologies are consistent with all returns falling to the return on currency concerns holdings of gold. There is considerable casual evidence that some gold has almost always been held purely as a store of value. Certainly, gold is being held as a store of value today. This implies that preferences and technologies are now consistent with the rate-of-return on gold holding its own vis-a-vis that on other assets. That being so, it seems far fetched to say that these conditions did not hold at other times--when gold happened to also serve as a medium of exchange. 


\section{Some Normative Implications of the Suggestion}

I will now apply the Hicksian vision of a world without frictions--which I interpret as arising entirely from laissezfaire in intermediation--to consider two long-standing issues in monetary economics: the welfare effects of inflation and the inefficiency of commodity money. To do this one needs an intertemporal model which permits there to be equilibria in which all real returns are equal to the return on money. Overlapping generations models permit this to happen and the results I will be discussing should be understood as arising in the context of such models.

As regards to the inefficiency of commodity money, it is helpful to recall Friedman's remark which, paraphrasing slightly, is as follows: Why expend resources to dig up gold simply in order to put it in a bank vault [1960, p. 5]. This remark captures the inefficiency of a commodity money if the only use of gold once it is dug up is as an asset. In this case, the gold is a costly to produce outside money and the inefficiency is measured by the resources used in digging it up. If, however, gold has other potential uses, as an input into the production of things that yield utility, then matters are less straightforward. If it is assumed that turning gold into a utility-yielding use now interferes with doing so at a later time, then the above paraphrase captures the inefficiency of commodity money only if it is interpreted to mean that the gold remains in the vault forever. An extreme technology of this sort was assumed in Sargent and Wallace [1983]. We assumed that gold could at any time be turned 
into a nondurable consumption good, but that each unit of gold could be used this way only once. With this sort of technology and with gold holding its own in terms of rate of return, there is nothing inefficient or even suboptimal about an equilibrium path in which gold is held for a finite number of periods and then turned into consumption. Holding it forever is inefficient, because then there is some consumption which is sacrificed.

Notice that on this interpretation of the inefficiency of commodity money, the inefficiency is implied by an assumption about alternative uses of gold and the holding of gold forever and that it applies whether or not gold is a commodity money in the usual sense. Thus, if we interpret our world economy today as on a path where gold will be held in vaults forever, then we would conclude that that path is inefficient. This basis for attributing inefficiency to the holding of gold in vaults provides grounds for indicting a formal commodity money system only if we think that even more gold would be held permanently in vaults under such a system.

A similar proviso arises regarding the welfare effects of inflation in a world with fiat money in which we regard inflation as being produced by money-financed deficits. With money holding its own in terms of rate of return, the usual wedge-type arguments regarding inefficiency do not apply. Instead, nonoptimality arises from all real returns being driven down below the natural growth rate permanently. In the context of a model with the usual one good neoclassical technology, nonoptimality is synonymous with a Tobin-Mundell effect that drives the capital 
labor ratio beyond the golden rule point permanently. With money holding its own in terms of rate of return, no distortion accompanies an inflation known to be temporary.

Finally, I want to say a word about the implications of the view I have been discussing for open-market operations. Not surprisingly, the view I have been discussing leaves little scope for monetary policy in the sense of open-market operations. With private intermediation keeping nominal interest rates low, it is as if we have a liquidity trap, with the trap produced through variations in the amount of privately supplied inside money.

A more detailed picture of this lack of scope for openmarket operations would go as follows. Suppose the money consists of small denomination, payable-to-bearer notes, and suppose there is a common and constant average-cost technology for producing and maintaining such notes--common to both the government and the private sector. Then, an open-market operation would do no more than shift the location of the intermediation between the private sector and the government or central bank. It would affect neither interest rates, the price level, nor anything else. In particular, there would not be any effects on the government's budgetary position. Thus, for example, if the government expands its intermediation, then its interest payments to the public fall, but the savings in interest payments are just matched by the increased costs of maintaining the higher real stock of government currency.

Now, admittedly, the common constant average cost assumption seems farfetched. It is, perhaps, more plausible that 
the provision of small denomination, bearer notes is a decreasing cost activity--maybe because the cost of inhibiting counterfeiting does not rise in proportion of the value of notes outstanding. While such considerations may justify a government monopoly on currency issue, they suggest that the problem of how the monopoly should be managed resembles the analogous problem for other decreasing costs industries.

\section{Legal Restrictions}

So far I have been discussing what the oversimplifying suggestion says would occur under laissez-faire. Now I want to discuss why we hardly ever observe laissez-faire in intermediation--why legal restrictions have been so prevalent.

One obvious motivation for legal restrictions on private intermediation is to enhance seigniorage possibilities by increasing the demand for government currency. Many of the legal restrictions in place in the world today seem motivated by that consideration.

A related, but more subtle motivation for legal restrictions arises in settings in which there is a potential for earning seigniorage not only on currency, but also on other government liabilities. There is such a potential if the government can sell bonds with a real return less than the growth rate. Bryant and Wallace [1984] described one such setting--a stationary, pure exchange, overlapping generations model in which all private saving ends up being in the form of government liabilities. They showed that if a positive real deficit could be financed by money issue only, the usual kind of seigniorage, then there are Pareto 
Superior equilibria that have the same deficit being financed partly by bonds. The bonds are large denomination securities whose presence along with that of divisible money implies that savers face a nonconstant return schedule on savings, a schedule which is increasing in the amount saved. This nonconstant schedule, which is synonymous with price discrimination, allows for better outcomes, given that the constant schedule would itself be distorting because a positive deficit is being financed. The nonconstant schedule is achieved by bonds which are available only in a minimum denomination and which pay a higher rate-of-return than that on divisible currency and by a legal restriction against intermediation of government bonds. The legal restriction prevents savers from getting together and sharing the large denomination bonds. If they could, then according to the model, only a constant return schedule on government liabilities would be possible.

Seigniorage does not, however, seem to motivate all actual and suggested legal restrictions on private intermediation. It did not motivate Adam Smith's proposals that private banks be allowed to issue notes only in some substantial minimum denomination and only notes payable upon demand. Nor did it motivate proposals in the United States for high required reserves behind demand deposits or note issues. And it did not seem to motivate England's Bank Charter Act, often called Peel's Act, which gave the Bank of England a monopoly on note issue and set a marginal 100 percent reserve requirement against note issue. In a paper somewhat inaptly entitled "The Real Bills Doctrine Versus 
the Quantity Theory: a Reconsideration," Sargent and Wallace [1982] poked fun at restrictions like those imposed by Peel's Act. We did so by interpreting the goal of the restrictions to be price stability and the restrictions themselves to be ones that force savings instruments for small savers to be 100 percent backed by outside money. In the context of an overlapping generations model, we imposed an endowment pattern that implied a fluctuating demand for private credit and showed that the restrictions would indeed stabilize the price level. They did so by separating the market for money, which had a stable demand under the restrictions, from the market for credit which had a fluctuating demand. However, and this is the sense in which we poked fun at the restrictions, this stable price level outcome, which is accompanied by a fluctuating nominal interest rate, is not Pareto Optimal. In contrast, absent the restrictions, there is an equilibrium with a fluctuating price level which is Pareto Optimal.

of course, it is possible that our model was missing crucial features that justify the restrictions imposed by Peel's Act. Jevons in Money and the Mechanism of Exchange attempted to defend Peel's Act:

The objectors to the Bank Charter Act urge that we want more currency, but they cannot really mean more metallic currency. We must not look to changes in the law to increase the amount of specie in the country, and, as I have remarked, any one can get sovereigns if he has the needful gold... What the currency theorists want, then, is not more gold, but more promises to pay gold. The Free-Banking School especially argue that it is among the elementary rights of an individual to 
make promises, and that each banker should be allowed to issue as many notes as he can get his customers to take, keeping such a reserve of metallic money, as he thinks in his own private discretion, sufficient to enable him to redeem his promises. But this free issue of paper representative money does not at all meet the difficulty of the money market, which is a want of gold, not of paper; on the contrary, an unlimited issue of paper would tend to reduce the already narrow margin of gold upon which we erect an enormous system of trade. [1918, pp. 307-8.]

Jevons was right in saying that the free banking school wanted more promises to pay gold. He may have been wrong in denying that such promises could meet the needs of the money market. The model just discussed has variable needs in the money market, which could arise from either a fluctuating demand for currency-like assets or from a fluctuating demand for credit. In it, allowing credit instruments to take a currency-like form would fill the needs of the money market. Admittedly, however, if fluctuations in the needs of the money market arise in other ways--for example, from fluctuations in the degree to which promises to pay gold are trusted--then that model is not applicable.

\section{Evidence}

I now want to report and comment on some evidence concerning what is probably the weakest link in the private intermediation story I have told: the claim that the public would accept privately issued, payable-to-bearer claims on government currency or commodity currency in the future as perfect substitutes for the currency itself. Unfortunately, the evidence con- 
sists mainly of nonquantitative reports of what seem like relatively minor incidents.

Although there is considerable experience both in Great Britain and the United States with payable-to-bearer notes issued by private banks, almost all of the experience occurs under the restriction that the issuer redeem notes on demand. The most substantial exception of which I am aware concerns notes with option clauses issued by Scottish banks during the period from 1760 to 1764 . (Such notes and notes in denominations smaller than one pound were eliminated by legislation in 1765.) According to Hugh Rockoff [1986], the option clause permitted banks to refuse immediate redemption and to repay later with interest. When banks chose to exercise the option, they would date notes brought in for payment to establish the final redemption date. Rockoff reports that notes subject to the option clause were readily accepted as currency. He does not, however, report directly on what happened to notes on which a bank chose to exercise the option.

Another kind of relevant evidence is experience with government securities that are payable-to-the-bearer and are titles to government currency in the future. Although such experience does not bear on whether the public would trust private promises to government currency in the future, it does throw light on how claims to currency in the future are treated. On this matter, the evidence is mixed.

One incident concerns the issue in India about four years ago of payable-to-the-bearer securities maturing in ten years and paying simple interest at 2 percent a year. The main 
attraction of these securities was that they were exempt from all taxes. A newspaper reported that the bonds, which the government had expected to be discounted, began to command a premium of 20 percent or more and passed from hand to hand in lieu of cash.

A related incident concerns U.S. experience with Liberty Bonds, which were issued during World War I as bearer securities. In this case, the evidence that such bonds circulated as currency from time to time comes from complaints by the government. The Secretary of the Treasury issued a statement entitled "On the Evils of Exchanging Merchandise for Liberty Bonds." The statement began as follows. "It has been brought to my attention that numbers of merchants throughout the country are offering to take Liberty Bonds at par, or even in some cases at a premium, in exchange for merchandise." The statement went on to decry the practice, explaining that it was not the intent of the government that these bonds substitute for currency, but rather that the bond issues were intended to stimulate saving.

Finally, Makinen and Woodward [1986] report on some French experience with small denomination, payable-to-the-bearer government bonds. Beginning in 1915 and until 1927, the French government made available interest-bearing securities sold at discount and in a variety of denominations, including some quite small denominations, and with maturities of three months, six months, and one year. The authors report that notes could be obtained at the fixed discount prices at all banks, post offices, and numerous local offices of the finance ministry. They also report that in most years of their existence, the quantity out- 
standing was comparable to that of the currency, which consisted of notes of the Bank of France. The authors cite as evidence that the securities were not treated as perfect substitutes for Bank of France notes a reported incident in which it seemed impossible to carry out transactions using these securities. More damaging to the view I have been describing is the mere coexistence of these securities and Bank of France notes, with the former available at a discount. According to that view, either Bank of France notes should have disappeared--all of them being used to purchase the interest-bearing notes--or government offices should have run out of the interest-bearing notes and been unable to meet the demand for them. Neither seemed to happen.

I can offer only two possible explanations. First the interest-bearing notes were not well designed to circulate as currency at their face value because the prominent number on them and the one which was in a convenient denomination was their selling price, not their face value. More serious, perhaps, is the possibility that the discount notes were not viewed as default-free claims to Bank of France notes. The authors themselves suggest this when they remark that there were "periodic crises in the 1920's during which the interest-bearing notes were allowed by the public to run off and be replaced by Bank of France notes."

\section{Concluding Remarks}

I now want to, as it were, come clean and explain my qualms about the oversimplifying suggestion. Earlier, I criticized money-in-the-utility-function and cash-in-advance models 
because they were silent about the qualities an asset must possess in order that it yield utility or serve as a medium of exchange. Those theories simply assert that an outside or government money possesses those qualities and that other things do not. In a way, the oversimplifying suggestion does no better. It simply asserts that whatever are those qualities, they can be duplicated by privately provided inside money, by private intermediation. For example, in describing the oversimplifying suggestion, I repeatedly talked about properties like denomination and payability-tothe-bearer, but I did not describe an explicit model in which there was a demand for assets with these qualities. I did not because neither I nor anyone else, so far as I know, has such a model.

My concern can be put differently. I have at best described a one-blade-of-the-scissors theory of nominal interest rates--the one blade being a perfectly elastic supply curve of currency-like assets implied by private intermediation. If such a supply curve is operative, then much can be said about the nature of equilibrium without saying much about demand. However, this presumes what is far from obvious: that it is legitimate to treat supply separately from demand in the contexts under discussion. Such separate treatment is legitimate if one set of features of the environment generate the demand for currency-like assets and an independent set generates the supply of private liabilities that can meet that demand. It is quite possible, though, that the features that generate a demand for small-denomination, payableto-the-bearer assets also have implications for supply, and, in 
particular, imply that there are natural barriers to the substitution of inside for outside currency-like assets. Given this possibility, you can appreciate why I have chosen to label the one-blade theory an oversimplifying suggestion. 


\section{References}

Bryant, J. B. and Wallace, N. (1984) A price discrimination analysis of monetary policy. Review of Economic Studies 51 (April): 279-88.

Friedman, M. (1960) A Program for Monetary Stability (Fordham University Press, New York).

Helpman, E. (1981) An exploration in the theory of exchange rate regimes. Journal of Political Economy 89 (October): 865-90.

Hicks, J. R. (1935) A suggestion for simplifying the theory of money. Economica.

Jevons, W. S. (1918) Money and the Mechanism of Exchange (D. Appleton, New York and London.)

Lucas, R. E., Jr. (1982) Interest rates and currency prices in a two-country world. Journal of Monetary Economics 10: 335360.

Makinen, G. E. and Woodward, G. T. (1986) Some anecdotal evidence relating to the legal restrictions theory of the demand for money. Journal of Political Economy 94 (April) 260-65.

Rockoff, H. (1986) Institutional requirements for stable free banking. Cato Journal 6 (Fal1) 617-34.

Samuelson, P. A. (1947) Foundations of economic analysis. Cambridge: Harvard University Press.

Sargent, T. and Wallace N. (1982) The real-bills doctrine versus the quantity theory: A reconsideration. Journal of Political Economy 90 (December): 1212-36.

(1983) A model of commodity money. Journal of Monetary Economies 12, 163-87. 